\title{
EVALUATIVE RESPONSES IN MODERN ENGLISH FICTION
}

\author{
Tetiana Myroniuk \\ Research and Educational Centre for Foreign Languages, National Academy of Sciences of \\ Ukraine, Kyiv, Ukraine \\ boboshko.tanya@gmail.com
}

\begin{abstract}
The process of communication implies information exchange, mutual influence, and evaluation of speakers. An addressee is an important participant of this process, yet little is known about him as a person who receives and evaluates an addresser's utterance. This is particularly significant because the addressee influences the further course of communication by his/her own responses due to the rules of turn taking. An evaluative response is thus an evaluative speech act that serves as the perlocutionary effect of an addresser's utterance and simultaneously expresses some intention concerning an interlocutor. The present paper aims to identify, classify and analyse the types of evaluative responses from a pragmatic perspective. The empirical material consists of 30 modern American and British novels, or 3400 dialogues containing evaluative responses. The theoretical basis of the investigation integrates the main principles of pragmalinguistics and speech act theory. In view of this, we suggested a pragmatic typology of evaluative responses based on an addressee's speech reaction to the received stimulus. The study claims the universality of an evaluative response as a speech act. It may provide not only emotional perception of reality but also contribute to its adequate comprehension and even exert direct or hidden influence on verbal and nonverbal actions of an interlocutor.
\end{abstract}

Keywords: addressee; evaluation; evaluative response; fiction; manipulation; pragmalinguistics; speech act theory.

\section{Introduction}

Evaluation is a crucial element of a person's everyday life. We evaluate others and are evaluated in accordance with our deeds and words. Moreover, the category of evaluation is attracting a considerable interest of researchers since it corresponds to the principles of modern linguistics (Kubryakova, 1995). Firstly, evaluation is human-centred, or anthropocentric. Secondly, its investigation involves other areas of study like psychology and philosophy. Finally, many linguists pay great attention to the communicative behaviour of speakers. Pragmalinguistics is a leading area that studies and interprets linguistic phenomena in different speech acts, including those which contain evaluation.

Within this framework, the category of evaluation is defined as a pragmatic and semantic category represented by evaluative units at all speech levels. Typically, these evaluative units convey positive, negative or ambivalent speaker's attitude to the message content. They aim to realise a communicative intention and achieve some perlocutionary effect (Prykhodko, 2016).

Modern linguistics offers a considerable amount of literature on the category of evaluation. A number of investigations into the semantic and cognitive nature of evaluation were made by Arutyunova (1999), Bednarek (2009), Ishchenko (2010), Kosmeda (2000), Martin and White (2005), Prykhodko (2016), Vol'f (2006), Wang and Xu (2013), and Wright (1997). Some researchers studied the functional and pragmatic specificity of positive and negative types of evaluation (Arutyunova, 1999; Halliday \& Matthiessen, 2014; Kosmeda, 2000; Krysanova, 1999; Prihodko, 2016; Shkitska, 2012; Vol'f, 2006; White, 2016) as well as the context of their realisation in different types of discourse (Breeze \& Olza, 2017; Honcharova, 2002; Thompson \& Alba-Juez, 2014). Honcharova (2002) and Vol'f (2006) suggested communicative evaluative models that included an addresser's aim, his/her tactics and their realisation, an addressee's response and a result of such an interaction. Most of the mentioned authors (Arutyunova, 1999; Breeze \& Olza, 2017; Honcharova, 2002; Krysanova, 1999; Shkitska, 2012; Vol'f, 2006) highlighted the importance of an addresser's evaluative utterance. However, there is still a need for a closer look at the addressee's utterance that contains evaluation. Traditionally, an addressee has been viewed as a recipient of an addresser's communicative intention (Arutyunova, 2012; Halliday \& Matthiessen, 2014; Pocheptsov, 2009), but in this paper, he/she is a person who evaluates an addresser's utterance or some other phenomena connected with a speech act. This fact is particularly significant as the addressee influences the further course of communication by his/her own responses due to the rules of turn-taking. Thus, the present study aims to identify, classify, and analyse the types of evaluative responses from a pragmatic perspective.

The term an evaluative response is defined as an evaluative speech act that serves as the perlocutionary effect of an addresser's utterance and simultaneously expresses some intention concerning the interlocutor. Pragmatic characteristics of evaluative responses are of a particular interest. They depend on both the mechanisms of speech influence and the contextually determined properties of linguistic units.

The structure of the article is organised as follows. We first describe the empirical material, determine the theoretical background and methods of the research. Then we follow by presenting our findings and 
testing them against representative samples chosen from modern fiction. Finally, we offer some concluding remarks and suggestions for further studies.

\section{Methods}

To carry out our research, we used the language material selected from modern American and British fiction. The overall number of such novels is 30, or about 11000 pages. For our analysis, we chose 3400 dialogues containing evaluative responses.

The theoretical basis of the investigation integrated the main principles of pragmalinguistics and speech act theory, namely (a) considering the language in action, in the process of functioning; (b) studying the role of a speaker, his/her intentions, and the rules of communication; (c) focusing on the relationship of an addresser and an addressee; (d) taking into account linguistic and extralinguistic conditions of communication; and (e) implementing the Cooperative principle and the Gricean maxims (Austin, 1975; Grice, 1975; Leech, 1983; Searle, 1976). This study involved a variety of methods. First, selective and descriptive methods were used to sample dialogues and identify evaluative responses. Second, a pragmatic analysis allowed us to develop and analyse a typology of evaluative responses in accordance with an addressee's speech reaction to an addresser's utterance. Finally, a quantitative analysis highlighted prominent characteristics of different types of evaluative responses and enabled us to make objective conclusions.

\section{Results and Discussion}

To achieve the aim of the study, we developed a pragmatic typology of evaluative responses. It was based on an addressee's speech reaction to the received stimulus. The investigation shows that evaluative responses may express the addressee's attitude to the addresser or another person, some phenomenon or object. Interestingly, evaluative responses may also exert manipulative influence on the addresser. This finding is consistent with the results of the previous studies (Van Dijk, 2006; Zirka, 2005). It can thus be reasonably assumed that there are proper and manipulative evaluative responses.

Table 1 presents the types of evaluative responses in accordance with the addressee's speech reaction to the addresser's utterance. It also provides the percentage of each type of evaluative responses in the selected dialogues.

Table 1

Types of evaluative responses

\begin{tabular}{|c|c|}
\hline Proper evaluative responses (83 \%): & Manipulative evaluative responses (17 \%): \\
\hline rational (24.1\%) & manipulation of image $(6.2 \%)$ \\
\hline emotional (23\%) & manipulation of personal values (6\%) \\
\hline logical (7.7\%) & manipulation of conventions (3\%) \\
\hline social (7.6\%) & manipulation of typical actions (1.8\%) \\
\hline ethical (7.3\%) & \\
\hline aesthetic (5.2\%) & \\
\hline sensory (4.5\%) & \\
\hline quantitative (3.6\%) & \\
\hline
\end{tabular}

Proper evaluative responses represent a direct, open expression of the addressee's attitude to the object of evaluation. In contrast to manipulative evaluative responses, they are prevalent in this typology making $83 \%$ of the analysed material. We distinguished this type of evaluative responses based on the classifications of partly evaluative meanings suggested by Arutyunova (1999) and Wright (1997).

Let us consider the types of proper evaluative responses and their pragmatic meaning. For their easier comprehension, we provide examples from modern fiction and their analysis. The evaluative units in each evaluative response are underlined. We use a solid line for verbal means and a dashed line for nonverbal means.

A rational evaluative response characterises practical consequences and the value of some action or object, determines its (in)effectiveness, and correspondence to the norm. In contrast to this, an emotional evaluative response represents an addressee's affective attitude regardless of real characteristics of an evaluation object. It aims to change the interlocutor's mood or behaviour and improve information perception. The dialogues (1) and (2) present rational and emotional evaluative responses, respectively:

"Have you had a good day?"

(1) "Busy," Nigel said. "But that's not unusual" (Rhodes, 2005, p. 203).

The addresser's illocutionary aim is to start and maintain a contact with the addressee. This speech act is successfully fulfiled because Nigel informs the wife of his daily routine. The man determines the 
correspondence of his evaluation of the spent day to the norm. A double negative here highlights an intense working schedule of the doctor that has become ordinary and normal for his way of life.

"What's the matter?" he said, looking amused.

(2) “I'm fed up with you," I said furiously (Fielding, 2000, p. 76).

This dialogue consists of both an emotional question about the addressee's feelings and her emotional evaluative response. The idiom to be fed up with smb represents annoyance of the addressee. In addition, a verbal representation of the evaluation is congruous with the manner of her speech (said furiously).

The analysis of the empirical data indicates that a logical evaluative response may express epistemic and deontic modality that help create the author's view of the communicative situation. Epistemic modality is concerned with (ir)reality, (im)possibility of some action or state of an evaluation object, while deontic modality presents agreement with an addresser's utterance or to an action, as in the example (3):

"Can I smoke?" she asked.

(3) "I don't care," he said. "Smoke till you choke, old gal" (Grisham, 2002, p. 93).

Not quite a friendly relationship of the interlocutors should be taken into account in the analysis of this dialogue. The addresser aims at getting the addressee's permission to smoke. The evaluative response is characterised by epistemic modality, namely a neutral evaluation of such a possibility (I don't care).

A social evaluative response emphasises the evaluation of both professional and social values and conventions. In contrast to this, an ethical evaluative response presents the evaluation of moral qualities and behaviour of a person. It is worth saying that social and ethical evaluative utterances do not rely upon a fixed notion of norm. The society in general and every person in particular is changing and their norms are changing as well. Let us turn to the corresponding examples (4) and (5):

"He certainly seems to have got his feet under the table with your family, doesn't he?"

(4) "Bob's a good mixer, he gets on with everyone," said Ruth (Barr, 2006, p. 333).

The addressee answers a verifying question and gives a social evaluation of another person. Moreover, a social evaluation is also present in the addresser's utterance. Evaluative idioms to get feet under the table with smb ("to feel confident in an unfamiliar situation") and a good mixer ("a friendly person") indicate the values of the society to which the interlocutors belong.

"I hope she didn't give you much trouble?"

(5) "Not at all. Compared to the type of prisoner I usually deal with she was a day at the beach" (Childress, 2003, p. 292).

A brother of the imprisoned woman asks an ethical question, which implies a positive response. A police officer confirms it (Not at all) and positively characterises the woman's behaviour. In particular, this is achieved due to a metaphor a day at the beach that denotes an easy work with such a kind of criminals and a possibility to have a rest at work.

An aesthetic evaluative response presents an addressee's evaluation of aesthetic qualities of people, objects or phenomena. Here aesthetic standards are strongly connected with the individual tastes of an evaluator and his/her attitude to an evaluation object, for instance:

"And how is da Liza?" Bramante whispered. "Proving to be a prodigy?" His voice was barbed, teasing and patronising.

(6) Leonardo mererely_let_out a long, long sigh $\underline{\text { L }}$ and said, "Oh dear. Oh dear. Oh dear. He has the face of an angel. His heart is sweet as honey. But his painting is akin to a donkey's. A blind donkey's" (Wright, 2006, p.106).

The addresser aims to determine artistic ability of the addressee's apprentice. The aesthetic evaluative response presents an ambivalent attitude to da Liza's talent. For this reason, Leonardo uses an adversative conjunction but and a contrast in comparing the boy's appearance with the quality of his paintings: the face of an angel; his heart is as sweet as honey; his painting is akin to a donkey's. The addressee intensifies the contrast due to parcelling, i.e. emphasising every component of the evaluative utterance. He also uses tautology (Oh dear. Oh dear. Oh dear) and nonverbal means (let out a long, long sigh) to express his disappointment.

On the contrary, a sensory evaluative response represents the evaluation of a person's physical and psychological experience. It differs from the rest of the types of evaluative responses because it does not rely on any norms, only a person's feelings. Therefore, it is the most individual type of evaluation. We distinguish several kinds of sensory evaluative responses, namely visual, auditory, gustatory, tactile, olfactory evaluation, and the evaluation of the state of health, e.g.:

"Are you sure you are well?"

(7) “Yes, I'm perfectly well," she replied firmly (King, 2007, p. 30).

The addresser inquires of his wife's health and gets a positive sensory evaluative response. An adverb 
perfectly, which intensifies an evaluative unit well, provides the persuasiveness of the addressee's evaluation. The woman's manner of speech (replied firmly) adds to the certainty of her words.

A quantitative evaluative response is the least frequent compared to the rest of the types of evaluative responses that fall together under the category of qualitative evaluative responses. Despite this division into opposite categories, a quantitative evaluative response presents quantitative properties in terms of quality of an evaluation object. It expresses (dis)approval of some quantity, for example:

"How old is he?"

(8) “Thirty-seven, Gramps. He thinks he's in his prime” (Montefiore, 2005, p. 185).

The addresser asks a 17-year-old granddaughter about her boyfriend's age. The girl knows that her grandmother will not approve of a great age difference. She gives a quantitative evaluation of the man's age and claims that he is in his prime. Therefore, the age of the evaluation object determines his qualitative characteristics.

The results of pragmatic and quantitative analyses indicated that rational $(24.1 \%)$ and emotional evaluative responses $(23 \%)$ were the most frequent in modern English fiction. Surprisingly, many works in this field suggest that evaluation tends to be emotional rather than rational (Arutyunova, 1999; Bednarek, 2009; Honcharova, 2002; Ishchenko, 2010; Prykhodko, 2016; Shkitska, 2012; Thompson \& Alba-Juez, 2014; Vol'f, 2006). In this paper, we prove the contrary since both of these types are equally frequent in the analysed novels. Evaluative responses may thus regulate and facilitate the interlocutors' activity as well as influence their emotional state.

Evaluative utterances are believed to be among significant means of manipulation. In the literature, manipulation is defined as a hidden, indirect psychological and communicative influence on a recipient that is conducted either spontaneously or deliberately. This process changes mutually connected algorithms of the recipient and functioning of his consciousness, subconsciousness, and unconsciousness (Kalita \& Taranenko, 2012). Besides, manipulative utterances may be identified due to the following features: a speaker treats an interlocutor as a means for achieving his/her own goals. Simultaneously, he/she creates the illusion thay the interlocutor independently makes a decision to act in the way that is beneficial for the manipulator. Psychologists and linguists (Dotsenko, 1997; Kalita \& Taranenko, 2012; Van Dijk, 2006; Zirka, 2005) agree on the main targets of manipulators: 1) conceptual picture of the world; 2) social conventions, beliefs, selfesteem; 3) interests and ideals; 4) behaviour, habits, way of thinking. Therefore, a manipulative evaluative response is a speech act that expresses evaluation for the purpose of indirect influence on a person's cognitive, emotional, and behavioural spheres of life. The above-mentioned targets of manipulators laid the basis for our typology of manipulative evaluative responses.

It should be noted that manipulative evaluative responses were also studied based on the analysis of violations of the Cooperative principle and the Gricean maxims (Grice, 1975). Our research material indicates that an addressee-manipulator often violates maxims of quality ("Do not say that for which you lack adequate evidence") and relation ("Be relevant"). The cases of the violation of maxims of quantity ("Make your contribution as informative as is required") and manner ("Be perspicuous") are also identified in the selected novels.

The essence of an evaluative response with the manipulation of image lies in an addressee's intention to impose evaluative association between the image and a relevant need, instruction, or interest upon an addresser. This evaluative response motivates the interlocutor's further activity according to the manipulator's wishes. Let us present the analysis of the evaluative response containing image manipulation:

"What do you mean?"

(9) "You're like a flower," he told her. "So fragile and pretty. I want to take care of you" (Baker, 2002, p. 36).

The addresser's aim here is to determine the addressee's intention concerning their relationship. The addresser's speech influence is successful, but the addressee deliberately violates the maxim of relation. To be more precise, the man appeals to the woman's need for safety and security. His wicked goal to seize the woman's possession is known from the context. The manipulation is fulfiled with a simile since it presents the image of the woman who is as tender and delicate as a flower and thus needs care. In addition, a parcelling intensifies the manipulative force due to a logical emphasis on key influential components.

An evaluative response with the manipulation of personal values presents an addressee's intention to evoke or destabilise an interlocutor's moral qualities, instructions, values and to use them for the manipulator's benefit, like in the example (10):

Mam was loud in his praise. "Isn't he kind?" she asked Suzy.

(10) Suzy couldn't believe it. "He's horrible to me," she said (Baker, 2002, p. 60).

The evaluation object here is an addresser's husband and a stepfather of the addressee. The woman 
intends to praise her husband's actions and maintain a friendly relationship in the family. However, the perlocutionary effect of her speech act is unsuccessful. The stepfather treats Suzy badly and she has to manipulate her mother's moral qualities and values. The girl uses a descriptive evaluative adjective horrible and intensifies it with a pronoun phrase to me that appeals to maternal feelings of the woman. Note that in this case the manipulation is realised to rescue both interlocutors from home tyranny. The dialogue (10) is an example of the violation of the maxim of quality, as Suzy doesn't support her words with evidence.

An evaluative response with the manipulation of conventions consists in an addressee's intention to use social norms, traditions, stereotypes, and their evaluation for his/her own or for an interlocutor's benefit. This evaluative response aims to change the addresser's verbal and nonverbal behaviour, e.g.:

"What if he has given me an expensive gift?"

(11) "It's quite improper for you to accept it. It reflects on your reputation" (Montefiore, 2005, p. 191).

A woman warns her young daughter against accepting expensive presents from a much older man. The addresser aims to persuade her mother that there is no ground for this warning, but the influence of her speech act is unsuccessful. The addressee manipulates conventional norms and rules that are significant for her daughter. A negative descriptive evaluative adjective improper and a noun reputation perform an implicit influence on the addresser. The girl values her reputation, so she considers her mother's words. Thus, the present manipulation of conventions is conducted for the addresser's benefit. The dialogue (11) is an instance of the violation of the maxim of manner since the mother's utterance is quite obscure.

It is necessary to stress the difference between evaluative responses with the manipulation of conventions and evaluative responses with the manipulation of personal values. The former is based on generally accepted rules, whereas the latter rests upon personal experience and values of speakers.

An evaluative response with the manipulation of typical actions shows an addressee's intention to form an addresser's evaluative attitude to people, phenomena, or objects in accordance with the automatic, typical mechanism of verbal and nonverbal actions in standard situations. Let us consider the example (12):

"Twenty-two hundred dollars?" Lucille tried to keep the shock off her face.

(12) "That's marked down from thirty. Believe me, it's a steal" (Childress, 2003, p. 152).

This dialogue describes a conversation between Lucille and a consultant of the expensive shop. The consultant has already persuaded the woman that the dress suits her and mentioned its price. Lucille refuses to buy the dress because of its high price, but the consultant uses manipulative evaluative means and violates the maxim of relevance. The consultant forms the addresser's positive attitude to the clothes in accordance with the automatic, typical mechanism in the situation of buying and selling. The addressee mentions a considerable discount (that does not really exist). The opportunity to buy nice clothes for less money is attractive and Lucy agrees. Here the phrase Believe me has a great influence and transforms the relationship between a seller and a buyer into a more intimate one. In the addressee's opinion, a noun steal is negative, thus the addresser believes that her request to reduce the price will be a crime against the consultant.

The data indicate that evaluative responses with the manipulation of image $(6.2 \%)$ and evaluative responses with the manipulation of personal values $(6 \%)$ are quite frequent in the analysed fiction. This tendency reveals a person's vulnerability to hidden influence on his/her needs, interests, moral qualities, and values.

\section{Conclusions}

In this article, we have presented the survey of the problem of an addressee as a dependent, though active participant of a speech act. Our research suggests that the addressee receives the addresser's communicative intentions as well as evaluates his/her utterance or some other phenomena connected with the speech act. Moreover, the addressee influences the further course of communication by his/her own responses due to the rules of turn-taking. We studied this issue of interpersonal communication within the framework of pragmalinguistics and used a set of corresponding methods. The applied methods allowed us to identify, classify and analyse the types of evaluative responses in accordance with the addressee's speech reaction to the addresser's utterance. Our work has led us to conclude that evaluative responses may contribute not only to emotional perception of reality but also ensure its adequate comprehension. Additionally, they provide direct or indirect influence on an interlocutor's verbal and nonverbal actions.

The theoretical and practical significance of the obtained results is determined by their contribution to pragmalinguistics and speech act theory. This study may be effective in harmonising communication, determining the manipulative nature of evaluative responses and avoiding such an influence. Our future work will focus on studying ethnic, cultural, and gender aspects of the category of evaluation and its manipulative influence. 


\section{References:}

Arutyunova, N. (1999). Yazyk i mir cheloveka [Language and the World of a Man] (2nd ed.). Moscow, Russia: Yazyki russkoi kultury.

Arutyunova, N. (2012). Logicheskij analiz yazyka. Adresatsiya diskursa [Logical analysis of the language. Discourse addressing]. Moscow, Russia: Indrik.

Austin, J. (1975). How to do things with words ( $2^{\text {nd }}$ ed.). Cambridge, USA: Harvard University Press. http://dx.doi.org/10.1093/acprof :oso/9780198245537.001.0001

Baker, A. (2002). Goodbye Liverpool. North Yorkshire, England: Magna.

Barr, E. (2006). Plan B. London, England: BCA.

Bednarek, M. (2009). Dimensions of evaluation: Cognitive and linguistic perspectives. Pragmatics and Cognition, 17(1), 146-175. http://dx.doi.org/10.1075/pc.17.1.05bed

Breeze, R., \& Olza, I. (2017). Evaluation in media discourse. European perspectives. Berlin, Germany: Peter Lang. http://dx.doi.org/10.3726/b10531

Childress, M. (2003). Crazy in Alabama. New York, USA: Ballantine Books.

Dotsenko, E. (1997). Psikhologiya manipulyatsii [Psychology of Manipulation]. Moscow, Russia: CheRo.

Fielding, H. (2000). Bridget Jones. The Edge of Reason. London, England: Picador.

Grice, H. (1975). Logic and conversation. In P. Cole \& J. Morgan (Eds.), Speech Acts (pp. 41-58). New York, USA: Academic Press. Grisham, J. (2002). The Summons. London, England: BCA.

Halliday, M., \& Matthiessen, C. (2014). Halliday's introduction to functional grammar (4th ed.). London, England and New York, USA: Routledge.

Honcharova, N. (2002). Aksiolohichna struktura anhlomovnoho dialohichnoho dyskursu (na materiali hudozhnoi prozy) [Axiological structure of English dialogical discourse (based on the fiction)]. Unpublished $\mathrm{PhD}$ thesis, Kyiv National Linguistic University.

Ishchenko, N. (2010). Otsinnyi komponent leksychnoho znachennia slova [Evaluative component of the lexical meaning of a word]. Filolohichni Traktaty, 2(3), 47-50.

Kalita, A., \& Taranenko, L. (2012). Rechevaya manipulyatsiya: opredelenie, funktsiya, mekhanizm realizatsii [Speech manipulation: definition, function, mechanism of realization]. Visnyk Kharkivskoho natsionalnoho universytetu imeni V.N. Karazina. Seriia "Romano-hermanska filolohiia. Metodyka vykladannia inozemnykh mov", 1022, 10-19.

King, C. (2007). Silk and Steel. London, England: Sphere.

Kosmeda, T. (2000). Aksiolohichni aspekty prahmalinhvistyky: formuvannia i rozvytok katehorii otsinky [Axiological aspects of pragmalinguistics: forming and developing the category of evaluation]. Lviv, Ukraine: Ivan Franko Lviv National University.

Krysanova, T. (1999). Vyslovliuvannia z nehatyvnoiu otsinkoiu adresata v suchasnii anhliiskii movi (komunikatyvno-prahmatychnyi aspekt) [Utterances with a negative evaluation of the addressee in modern English language (communicative-pragmatic aspect)]. Unpublished PhD thesis, Kyiv State Linguistic University.

Kubryakova, E. (1995). Evolyutsia lingvisticheskikh idej vo vtoroj polovine XX veka [Evolution of linguistic ideas in the second half of XX century]. In Y. Stepanov (Ed.), Yazyk i nauka kontsa XX veka [Language and science at the end of XX century] (pp.144-238). Moscow, Russia: Institut yazykoznania RAN.

Leech, G. (1983). Principles of pragmatics. London, England: Longman.

Martin, J., \& White, P. (2005). The language of evaluation. Appraisal in English. New York, USA: Palgrave Macmillan. http://dx.doi.org/10.1057/9780230511910

Montefiore, S. (2005). Last voyage of the Valentina. London, England: BCA.

Pocheptsov, G. (2009). Izbrannye trudy po lingvistike [Selected works in linguistics]. Kharkiv, Ukraine: V.N. Karazin Kharkiv national university.

Prihodko, A. (2016). Cognitive-communicative organization of the evaluative frame. Lege Artis, 1(1), 275-308. http://dx.doi.org/10.1515/lart-2016-0006

Prykhodko, H. (2016). Katehoriia otsinky v konteksti zminy linhvistychnykh paradyhm [The category of evaluation in the context of the change of linguistic paradigms]. Zaporizhzhia, Ukraine: Kruhozir.

Rhodes, E. (2005). Mixed blessings. London, England: BCA.

Searle, J. (1976). A classification of illocutionary acts. Language in society, 5(1), 1-23. http://dx.doi.org/10.1017/s0047404500006837

Shkitska, I. (2012). Manipuliatyvni taktyky pozytyvu: linhvistychnyi aspekt [Manipulative positive tactics: a linguistic aspect]. Kyiv, Ukraine: Publishing house of Dmytro Buraho.

Thompson, G., \& Alba-Juez, L. (Eds.) (2014). Evaluation in context. Amsterdam, Netherlands: John Benjamins Publishing Company. https://doi.org/10.1075/pbns.242

Van Dijk, T. (2006). Discourse and manipulation. Discourse \& Society, 7(3), 359-383. http://dx.doi.org/10.1177/0957926506060250

Vol'f, E. (2006). Funktsional'naya semantika otsenki [Functional semantics of evaluation] (2nd ed.). Moscow, Russia: Editorial URSS.

Wang, Y., \& Xu, J. (2013). The interrelation between evaluative categories and evaluated items. Linguistics and the Human sciences, 8(1), 29-61. http://dx.doi.org/10.1558/lhs.v8i1.29

White, P. (2016). Evaluative contents in verbal communication. In A. Rocci \& L. Saussure (Eds.), Verbal communication (pp. 7796). Berlin, Germany: De Gruyter Mouton. https://doi.org/10.1515/9783110255478-006

Wright, G. (1997). The varieties of goodness (2nd ed.). Bristol, England: Thoemmes Press.

Wright, D. (2006). The History of Lucy's Love Life in 10 1/2 Chapters. London, England: Sphere.

Zirka, V. (2005). Yazykovaya paradigma manipulyativnoj igry $v$ reklame [Language paradigm of the manipulative game in advertising]. Unpublished doctoral thesis, Dnipropetrovsk National University. 